InOedia $\quad \begin{aligned} & \text { InMedia } \\ & \text { The French Journal of Media Studies }\end{aligned}$

7.2. $\mid 2019$

Documentary and Entertainment

\title{
Expanded Documentary: The Aesthetics of Pleasure
}

\section{Keith Marley}

\section{(2) OpenEdition}

\section{Journals}

Electronic version

URL: http://journals.openedition.org/inmedia/1748

DOI: 10.4000/inmedia.1748

ISSN: 2259-4728

\section{Publisher}

Center for Research on the English-Speaking World (CREW)

\section{Printed version}

Date of publication: 15 December 2019

\section{Electronic reference}

Keith Marley, "Expanded Documentary: The Aesthetics of Pleasure", InMedia [Online], 7.2. | 2019, Online since 19 December 2019, connection on 26 January 2021. URL: http://journals.openedition.org/ inmedia/1748 ; DOI: https://doi.org/10.4000/inmedia.1748

This text was automatically generated on 26 January 2021.

(c) InMedia 


\title{
Expanded Documentary: The Aesthetics of Pleasure
}

\author{
Keith Marley
}

\section{Introduction}

1 Many of the debates associated with the idea of documentary being seen as a form of entertainment have tended to focus on documentary film's link with reality TV and TV infotainment; however, in this article I aim to conceptualize documentary as entertainment in two wholly different ways by, first, focusing on how documentary aesthetics can be conceived as a form of entertainment and, second, by outlining how sites of exhibition not normally associated with documentary can function as spaces for entertainment and pleasure.

2 In terms of critical context, the discussion on aesthetics as entertainment will be framed by Nichols' work on documentary modes ${ }^{1}$. In his writings Nichols identified a series of documentary modes, each one being defined by a set of formal characteristics that belong to each particular mode. His six modes include the poetic, expository, observational, participatory, reflexive, and performative. For this article I will pay particular reference to the poetic mode. I will also use the work of Keith Beattie and his concept of documentary display ${ }^{2}$.

3 For the discussion on documentary exhibition as spaces of entertainment and pleasure, I have built on the work of Gene Youngblood ${ }^{3}$, whereby he introduced the concept of expanded cinema. I use the term expanded documentary as a way of describing both innovative formal aspects of documentary and its subsequent exhibition in new spaces.

\section{Statement of Intent}

4 It is fair to say that documentary filmmakers aim to have an impact on audiences. They may wish to inform or educate, highlight social injustice, challenge dominant discourses associated with a particular topic or they may wish to merely entertain an 
audience. As a documentary filmmaker myself, the aim of the work that I produce seeks to operate at the level of perception, sensory experience, and affect rather than to address, say, any social injustice or challenge any particular dominant discourse. In order to achieve this, particular attention is paid to the formal aspects of my films, as opposed to the actual content of my films. It is my intention to attempt to engage audiences in an affective way, so that they can experience a degree of pleasure in the aesthetic qualities of documentary work.

5 I am particularly interested in capturing documentary images of the everyday and then render them as evocative and aesthetically pleasing through a series of technical and aesthetic devices; these include editing techniques, the compositional quality of shots, sound design and innovative forms of projection and exhibition. The overall aim is to encourage the viewer to see and hear the world in a different way and for the audience to engage with the aesthetics of the documentary film world in a more significant and contemplative way. It is my argument here that viewers can benefit from engaging with a documentary that is driven by aesthetics rather than by an expositional impulse. By encouraging an audience to see and hear the lyrical potential of documentary, a film can operate more on the level of evocation via the filmmaker's focus on the aesthetic, as opposed to the expositional, potential of documentary film. As such, the filmmaker can elevate the audience to a more active and informed reader of audio-visual texts. It is through the particular formal qualities of a documentary film, that one can achieve what Renov calls "pleasurable learning." ${ }^{4}$

\section{The Aesthetics of Pleasure}

We are promoting propaganda using facts, not on the level of vision alone, but on that of hearing too...If, with respect to vision, our kinok-observers have recorded visible life phenomena with cameras, we must now talk about recording audible facts. We're aware of one recording device; the gramophone. But there are others more perfect; they record every rustle, every whisper, the sound of a waterfall, a public speaker's address...Technology is moving swiftly ahead. A method for broadcasting images by radio has already been invented. In addition, a method for recording auditory phenomena on film tape has been discovered. In the near future man will be able to broadcast to the entire world the visual and auditory phenomena recorded by the radio-movie camera. ${ }^{5}$

In order to offer an alternative vision as to what documentary film can achieve through aesthetic innovation, it would be pertinent to assess how the history of documentary film has helped to develop particular formal conventions of representation in nonfiction filmmaking. One of the major figures in that history, John Grierson, helped forge the trajectory of documentary filmmaking from the 1920s until his death in 1972. In many ways Grierson's legacy continues to leave an imprint on much of contemporary documentary filmmaking. For Grierson, civic education was the key to creating an informed and civilized society, with documentary playing a central role in creating an informed mass. Grierson rejected forms of avant-garde practices within documentary filmmaking, arguing that textual difficulty should be avoided at all costs, claiming that avant-garde modes of representation were antithetical to the civic project of documentary film. For Grierson, documentary "was from the beginning an antiaesthetic movement."' As a result of Grierson's legacy, Bill Nichols claims that documentary practice has suffered from what he calls "discourses of sobriety", whereby documentary is associated with other nonfiction systems such as science, 
religion, economics, education and politics. ${ }^{7}$. According to Keith Beattie, this association with seriousness and sobriety has restricted aesthetic development within documentary practice, thus producing a canon of films that are underdeveloped and unremarkable in terms of their representational strategies, whereby "aesthetic innovation is generally subservient to documentary convention"s. It is with this in mind that I wish to explore the idea of the aesthetics of pleasure, whereby the form of documentary film becomes a central feature in its capability to engage audiences in significant ways, rather than to simply inform. It is my argument here that the viewer/ listener can experience pleasure and entertainment from engaging with innovative representational strategies that are not normally seen and heard in much of mainstream documentary practice.

While documentary film was being stablished in the UK, an alternative canon of documentary films was developing in Continental Europe. While it would be unfair to say that the European documentary canon was not concerned with social, cultural, and political issues as the British documentarians primarily were, there is no doubt that a central concern for European documentary focused on the development of the documentary form itself. Filmmakers such as Dziga Vertov, Jean Vigo, Joris Ivens, and Alberto Cavalcanti became innovators in the development of documentary film. Two of the most prominent members of the British documentary film movement, Paul Rotha and Grierson, were critical of this continental model, claiming that formal concerns took precedence over social message, as Grierson's rather polemic views indicate.

Creation indicates not the making of things but the making of virtues...beauty will come in good time to inhabit the statement which is honest and lucid and deeply felt and which fulfils the best ends of citizenship...the self-conscious pursuit of beauty, the pursuit of art for art's sake...was always a reflection of selfish wealth, selfish leisure and aesthetic decadence. ${ }^{9}$

8 The denial of an aesthetic approach to documentary filmmaking is unfortunate. In my own documentary practice, my aesthetic approach to filmmaking has largely been informed by the poetic and avant-garde practice associated with many of these early European pioneers, with a particular emphasis being placed on the poetic and lyrical qualities of documentary images and sound. Films such as Regen (dir. Joris Ivens 1929), a lyrical visualization of patterns of rainfall in Amsterdam, makes no attempt to inform the spectator in any obvious way, rather the film medium here is used as a poetic device. This is evidenced through the careful composition of shots and the lyrical juxtapositions created through precise editing. Shots are linked together by their graphical and temporal aspects, with the pace of editing producing a satisfying rhythm and narrative structure; overall it is a film that appeals to the senses rather than the intellect, whereby the audience can seek pleasure in the aesthetic, rather than informative, qualities of documentary film. It is a film that aims to show rain rather than tell us about rain. It is evocation rather than exposition. The idea of showing rather than telling is closely associated with Keith Beattie's concept of documentary display. In defining documentary display, Beattie states that aesthetic strategies are often innovative and expressive, reminiscent of the work associated with the European documentary filmmakers of the 1920s, such as Vertov, Leger, Ivens, and Vigo. This emphasis on aesthetics aims to free the filmmaker from the demands of knowledge production, allowing the filmmaker to create a documentary that "entertains, startles and excites in ways which produce pleasure". ${ }^{10}$ Knowledge production then becomes something that is visceral, subjective and affective and is achieved through a film's 
aesthetics, which operates on a sensorial, rather than cognitive, level. For Beattie, if a film operates merely on a cognitive level, then associations with pleasure and entertainment become limited.

One effect of the imposition of a representation of rational truth as the core of documentary is to reduce documentary to the realm of the serious where the pleasure and associated conceptions of fun are weakened or attenuated - to the point that documentary is characterized as a discourse of sobriety. ${ }^{11}$

Beattie applies the concept of documentary display to the "City Symphony" makers of the 1920s and 1930s. Filmmakers such as Dziga Vertov, Walter Ruttman, Jean Vigo, and Alberto Cavalcanti all created dawn-to-dusk vignettes of European cities. These films do not intend to tell the audience about particular cities, rather they aimed to show the audience particular cities. "City Symphonies" reject explicit rhetorical structure and instead look to capture the mood, rhythm, and atmosphere of a particular place and are more interested in aesthetic expression, rather than conveying the real. In many ways they become a tangible form of a cinema of attractions, whereby emphasis is placed on the experiential, rather than narrational, pleasure of a text. Beattie argues that these films have a function beyond telling and can produce alternative forms of seeing and knowing.

10 This focus on an audience finding pleasure in a documentary's aesthetic has become the driving force in my own practice. For example, in 2010 Dr. Geoffrey Cox and I, produced a contemporary take on the "City Symphony", A Film About Nice ${ }^{12}$ (dir. Keith Marley 2010). In one of the scenes in the film I include a long take (approximately one minute in length) of a speedboat hauling a holiday maker attached to a parachute 50 metres above the sea (see figure 1 below). Sitting in this spot filming the boat was a very relaxing and pleasurable experience, and as a filmmaker I make a series of aesthetic choices in order to give the viewer a sense of being there. In order for me to be able to express the pleasurable nature of this scenario there is a necessity to create a sense of feeling, rather than knowing. As such, I focus on the aesthetic dimension of filmmaking, which appeals directly to the senses.

11 In this scene I used a wide-angle lens, ensuring that the boat would take a long time to enter screen right and exit screen left. This allows the audience to meditate on the movement of the boat and encourages a more contemplative mode of viewing. There is no inherent need for the viewer to search for any meaning within this scene as I do not aim to appeal to the viewer's cognitive processing capabilities; rather I aim to operate at the level of evocation. The audio track is equally as minimalist in terms of its content, which consists of close up recordings of the sea lapping onto pebbles, as well as the gentle hubbub of people chatting on the beach and seagulls calling in the distance. Again there is no attempt to encourage an interpretive mode of listening here; rather the listener is encouraged to adopt a mode of listening that encourages feelings, independent of the referential aspects of any particular sounds. It is, in terms of both sound and image, a poetic, rather than informative, style of documentary filmmaking. Beattie claims this type of filmmaking produces a form of affective knowing, which is achieved through "various camera movements and associated markings of time and place; long takes which alternately frame action or a meditative stillness". ${ }^{13}$

12 My attempt to achieve this affective turn in documentary representation initially relies on developing certain aesthetic techniques, achieved in particular by the careful composition of shots. David MacDougal argues that effective framing of shots 
encourages the viewer to look more carefully at the subject. Careful and considerate composition imbues a greater degree of significance in the subject matter, whereby "such intensifications and reinforcements of perception may make us, as viewers, more observant in our daily lives." ${ }^{14}$ In essence, this approach to filmmaking becomes part of a process that encourages the viewer to "re-see" the world around them.

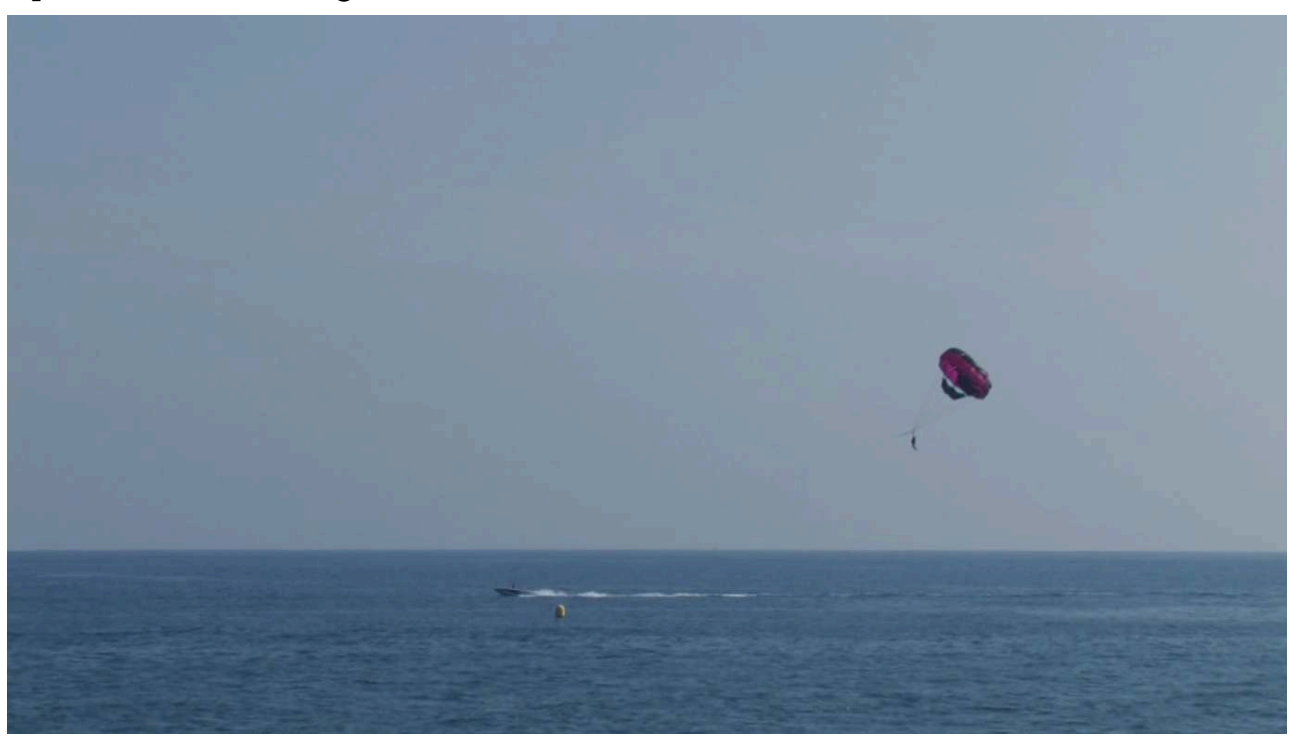

Figure 1 A Film About Nice

13 As an alternative to scenes of meditative stillness, Beattie also claims that the "origins of display are aligned with the series of visual excitements and shocks characteristic of a "cinema of attractions" 15 In the same film, various scenes that are filmed in the downtown area of Nice, the atmosphere is much different to that by the sea. The traffic is chaotic and the pace of life is much more frantic. The aesthetic of the film changes significantly; editing is much more rapid, sounds of engines, sirens, airplanes and assorted bangs, such as car doors slamming, are arranged in ways that produce an immersive cacophony of sounds. The graphical movement within the frame is sequenced in ways that emphasise the chaotic nature of this area of Nice. Cars and mopeds move right to left, then cut to movement from left to right. Sounds are panned, in order to complement the image, or at times to act in counterpoint, with the cacophony of sounds and rapid pace of editing helping to produce the visual excitement and shock factor of what Beattie claims are inherent in a cinema of attractions.

In films like "City Symphonies", the lack of voice-over, intertitles or other informational devices associated with the expository mode of documentary filmmaking, allows the audiences to focus on the aesthetic dimension of the film itself. The poetic mode can be seen as having a much more complex pattern of signification than the other more conventional modes, such as observational, expository, and participatory. The audience are invited to engage the senses in a deeper way, and as such take pleasure in decoding a text, where the discourse is not so obvious. Renov valorizes the place of poetics within documentary discourse, suggesting that aesthetics which challenge or "activate" the spectator can produce pleasure in learning:

The ability to evoke emotional response or induce pleasure in the spectator by formal means, to generate lyric power through shadings of sound and image in a manner exclusive of verbalization, or to engage with the musical or poetic qualities 
of language itself must not be seen as mere distractions from the main event.

Documentary culture is clearly worse for such aesthetic straightjacketing. ${ }^{16}$ I have developed. The sonic element of documentary practice, so often overlooked and underdeveloped in much mainstream filmmaking, can engage the senses in a more significant way than image alone. Sound is incisive, it penetrates in ways that is different to that of the image and is arguably more direct and powerful. Sound is internalized, it can provoke memories, create mind's eye images, it can instantly promote happiness, sadness or trepidation and if treated in attentive ways by the documentary maker, it can transport the viewer/listener to a place other than which they are inhabiting. It unsettles, it comforts, it conveys and ultimately has the ability to imbue actuality footage with a greater degree of significance.

In order to hail the listener in the first instance, careful consideration has first to be given to the way the image track of a documentary is composed, so that cognitive processing is freed up in order for the viewer/listener to spend more time on listening to the sounds themselves, rather than on decoding obvious narrative cues, or trying to take in information via a voice-over or graphical information on screen. Therefore, if the complexity of the image track is simplified, then it is hoped that the viewer/ listener's attention will indeed focus on the sonic element of the film. This could be achieved, for example, through the use of a long take, with minimal action in the frame, as in the aforementioned boat and parachute shot. Michel Chion claims that the viewer/listener takes more time to process via the eye than the ear: "the ear analyzes, processes, and synthesizes faster than the eye...the eye perceives more slowly because it has more work to do; it must explore in space as well as follow along in time." ${ }_{17}$ Therefore in Nice the image track is often simplistic giving the shot a minimalist feel in terms of both composition and movement within the frame to allow focus to shift to the audio. Long takes of waves lapping onto a beach, or a boat drifting in a harbor, have a certain degree of simplicity and stand in contrast to the complexity of the audio track. All of the sounds were recorded on location, none were added outside of the sonic diegesis of the Côte D'Azur; they were often layered into complex patterns, sometimes in synchronicity with the images, at other times they would be used in an asynchronous manner. Cox articulates our approach by stating that our "aim here was to encourage the listener/viewer to concentrate on the sound, even to adopt Pierre Schaeffer's concept of 'reduced listening' where one listens to the sound, so as to focus on the traits of the sound itself, independent of its cause and meaning." ${ }^{18}$ In this sense, any significance found within the sonic track is purely a matter of interpretation for the listener to decode their own meanings. Cox and I were not intent on attempting to attach any kind of specific symbolic significance to the sounds used; rather the individual sounds were orchestrated in ways that made musical sense, rather than trying to encode specific meanings. Ultimately we wanted the audience to find pleasure in the soundtrack in order to find it interesting and enjoyable in its own right. Once the banal everyday images have been re-contextualized through filmic devices, then audiences arguably have a greater opportunity to marvel at the world around them, achieved through a cinematic re-seeing and re-hearing of that world. MacDougal argues that the filmmaking process inherently produces a filmmaker with heightened awareness, and as such, if the filmmaker intends to create a more sophisticated and aware viewer, then surely it is at the level of the aesthetic where the filmmaker uses cinematic tools to forge a new way of seeing and hearing. 
Exactly why one should wish to show others what one has seen is another matter. Is it an affirmation of the thing itself, or of one's own vision, or a desire to command the consciousness of others? Or is it perhaps to transcend one's self, to overflow one's self-containment. ${ }^{19}$

\section{Expanded Documentary}

17 In order to engage the viewer on a more sensorial level, I began to develop the concept of expanded documentary. Expanded documentary relates to both the development of innovative representational strategies, as discussed above, as well as the use of novel spaces of exhibition. Much of my conceptual framework has been informed by Gene Youngblood's concept of expanded cinema, a term he first introduced in 1970. Its overall premise was to create a cinema that moved away from its traditional spaces of exhibition (such as the picture house) into new spaces of exhibition such as the art gallery, the nightclub, and the gig space. Perhaps the most famous examples of expanded cinema are Andy Warhol's collaborations with The Velvet Underground, known as "happenings". During these events the bands would play live to a backdrop of kaleidoscopic visuals made up of found film footage and also psychedelic projections created by dripping coloured inks onto oil and projecting the fractals onto multiple screens. There would also be the use of strobe lighting, dry ice and dancers taking to the stage. The real success of these ventures was Warhol's Exploding Plastic Inevitable (1966), which Youngblood describes as a "hellish sensorium...an experience, not an idea." ${ }^{20}$ It is within this context that I developed the idea of expanded documentary, which I first introduced at the Documentary Now! Conference in London 2010. Expanded documentary makes use of audio-visual actuality footage (as well as sampled found footage) and uses technologies that are more associated with VJ and DJ Culture ${ }^{21}$ to deliver a semi-improvised live set. VJ/DJ technology includes hardware and software that can be used to playback video/audio loops, as well as render real time effects, such as slow motion, reverse playback, mirror imaging, colour effects and so on. It is also possible to re-time video loops so that they playback in time with the beats per minute of any given tune that is playing, by pre-programming the video samplers, or VJ software. As such, it is possible to edit video sequences on the fly that are in synch with the rhythm of the soundtrack. This is fairly standard VJ practice; however it is the use of actuality footage that makes the link between VJ/DJ culture and documentary film. Hardware and software can also be pre-programmed to sequence sounds and images in a random, automated fashion. For example, let's say there is an electronic track playing at 120 beats per minute, video loops can be programmed so that they play back in time with the music. This is especially effective when using footage of dancers, who will appear to be dancing in time with the music. The hardware/software can also be programmed to cut between images in time with the end of, say, a four-bar musical sequence. The VJ can also trigger loops manually in time with the music, which all combine to provide the audience with a tangible structure to the images and offer a pleasurable viewing/listening experience; there is certainly pleasure to be had from seeing sound and image working in harmony.

In this instance it is not simply the aesthetics of a said text that can be seen as entertaining, but also the space in which the documentary is performed can become both a place of pleasure, as well as social learning. For example, the nightclub space has obvious associations with pleasure, however through the combination of music, live 
sound design, and visual performance, a link can be forged between entertainment and civic education. In many ways the viewer/listener becomes an active participant within the performance as they are free to move around the space and the viewer/listener can become an element in the performance itself. In previous live documentary events that Cox and I have performed, we have used cameras to film the audience live and then include the live stream into the visual mix. This attempt to include the audience as part of the overall text, encourages a greater sense of spectator engagement and helps to break down the divisions between spectator, author, and text.

It is interesting to note that when DJ/VJ started to become a significant part of youth culture in the late 80s, early 90s in Britain, much of the visual accompaniment was a particular kind of imagery, which mainly consisted of animated computer-generated fractal patterns. This is rather disappointing from the perspective of a documentarian. While this imagery is pleasant to watch and works well in the club environment, it has no documentary value whatsoever. It is purely "visual confectionary" for mere entertainment value. However, through the use of actuality footage as VJ content, the phenomenon of expanded documentary has the ability to inform, educate, and entertain, as well as bringing documentary culture into the mass arena rather than it being marginalized through more bourgeois spaces of exhibition, such as the arthouse cinema, film festival, or gallery.

The idea of using actuality footage within a live performance goes back way beyond Warhol's "happenings". Two of the major art movements of the early 20th Century, futurism and constructivism, aimed to bring avant-garde documentary practice to the masses by staging live multimedia art events in the 1910s and 20s, located outside of the bourgeois art galleries in order to garner as wide an audience as possible: 'The Futurists turned their backs on the sheltered cultured intellectual...and the rejection of society implicit in the traditional bohemian withdrawal, [and] opted for the public arena" 22 . In light of this, within a contemporary context, the night club environment provides a dynamic exhibition space, which is not necessarily linked with the more bourgeois associations of the art gallery or museum. As such, the potential for introducing new audiences to documentary film and to avant-garde modes of documentary representation is made possible.

The idea of expanded clubbing, which includes documentary as a central element, aims to provide new ways for audiences to experience the documentary text, as well as providing a more "immersive" clubbing experience. A central aesthetic within this form of documentary practice is montage, which echoes the aesthetics of both the futurists and the constructivists. The hardware and software naturally lend themselves to a montage style of editing, especially if the sequences of images are automated by the machines or software in any way. Narratives are no longer fixed, nor linear, and the text itself is only experienced in the "here and now" of the performance and will be wholly ephemeral if there is no actual recording of the live performance. In her book, Documentary Time: Film and Phenomenology, Malin Wahlberg argues that "the sensory and affective implications of temporalization in moving images are crucial to the attraction and pleasures of film viewing" ${ }^{23}$. Wahlberg claims that documentary film has a sense of immediacy, in that the image is experienced in real-time viewing, but also that the documentary text, being a representation of a historical past, acts "simultaneously as an image of the present and a trace of the past...[and] provides a model of perception according to which the film frame metonymically refers to the mental image of a past 
event, inscribed by the mnemonic processes of our brain" ${ }^{24}$. As such, any analysis of the effects of documentary should take into account not only the construction of the text itself and its possible interpretations, but also the actual experiences and perceptions of the audience at the time of documentary exhibition.

As a consequence of this relocation of documentary exhibition to the club space, there exists an opportunity for the audience to not only experience a sense of pleasure in association to documentary, but also to actively engage in the questioning of the constructed nature of reality itself. The VJ, because he or she is present at the moment of authorship, can be seen as actively constructing and authoring a representation of reality, which is otherwise not apparent in more traditional forms of documentary film practice. Subsequently, the experience of live documentary allows the immersive nature of sound and image to produce a new perceptual reality in itself and, as such, encourages a "re-seeing" of the world.

\section{The Sensory Experience of Expanded Documentary}

The idea of documentary producing a "re-seeing" of the world is closely linked to the intentions of one of the great documentary filmmakers, Dziga Vertov. He argued that documentary has the ability to change an audience's perception if film technique is used in particular ways. Vertov and his associates in the constructivist and futurists movements heralded new industrial technologies, much in the same way as those who were connected with expanded cinema heralded new digital technologies. They also share a similar creative sensibility in that kinesis is a central aesthetic feature of both futurism and constructivism, as much as it is in expanded cinema.

The term kinetic generally indicates motion of material bodies and the forces and energies associated with it. Thus to isolate a certain type of film as kinetic and therefore different to other films means we're talking about different forces and energies than about matter. Kinaesthetic therefore is the manner of experiencing a thing through the forces and energies associated with its motion. This is called kinaesthesia, the experience of sensory perception...It's not what we're seeing so much as the process and effect seeing: that is, the phenomenon of experience itself, which exists only in the viewer. ${ }^{25}$

This interest in the way media can impact and mould human perception was also shared by Vertov, who developed his "Theory of Intervals", which, Vlada Petrić claims, "draws a lot from the constructivist conception of film as a 'building' comprised of many bits and pieces whose ultimate meaning depends on the interrelationship between various components. ${ }^{26}$. For Vertov, a montage style of editing creates a higher level of meaning through the combination and collision between shots. Meaning is not simply contained within the images, rather meaning is created when two shots are juxtaposed. This is, of course, an aesthetic that is easily recreated through the use of $\mathrm{VJ}$ technologies, with non-linear montage being a central aesthetic that is associated with these technologies.

Petrić goes on to argue that Vertov "achieved a high degree of cinematic abstraction through the battle of different visual structures and movements, producing a 'kinetic impact', the basis of kinaesthesia, the most unique experience that cinema can provide." ${ }^{27}$ This emphasis on the interrelationship between film's components echoes the ideas of Youngblood and his insistence on the unification of intermedia, whereby the "dynamic interaction of formal proportions in kinaesthetic cinema evokes 
cognition in the inarticulate conscious, which I call kinetic empathy." ${ }^{28}$ It is apparent that both Vertov and those associated with expanded cinema were intent on creating an experience that could change the perceptual nature of humans. A form of propaganda no less, but one that was not necessarily driven by rhetoric, rather one that was driven, in a phenomenological sense, by energy and forces, or what Vertov called, in his "We: Variant of a Manifesto" (1922), kineticheskoe rezreshenie (kinetic resolution $)^{29}$.

There are other contemporary examples of documentary being a central feature of a multimedia event. The recent collaboration between documentary filmmaker Adam Curtis and the musician and artist Robert Del Naja provides a useful example of the immersive nature of multi-media events. Curtis provided the visual backdrop to Del Naja's band, Massive Attack, during a gig at Manchester International Festival 2013. The event took place in a disused warehouse at the back of Piccadilly Station. The stark interior of the warehouse was adorned with multiple screens, configured into a 3-sided wall of images, with the audience of around 1500 people surrounded on 3 sides by a barrage of images, accompanied by the foreboding trip-hop of Massive Attack. The soundtrack also included audio-samples from news stories, well known films, television adverts, political speeches and so on. The overall aesthetic is closely reminiscent of Warhol's happenings discussed above. An incessant cacophony of sound and image bombarded the audience. The images Curtis used were sampled from a range of sources, such as films, television programmes, news reports, television adverts, CCTV cameras, military footage and the quick-fire montages were often played in time to the beat of the music, rather as a VJ would do in a club environment. This is very much in keeping with the concept of expanded documentary, whereby actuality footage is sequenced in particular ways in order to have a powerful impact on the spectator.

The overall cinematic experience is also very much in keeping with Youngblood's concept of kinaesthetic cinema discussed above and can also be closely related to the montage work of Dziga Vertov. It is evident that Curtis and Del Naja aimed to present a certain ideological perspective on the cultural logic of late capitalism. Their message can be read as an anti-capitalist polemic, which, through the use of montage editing, set out to encourage the audience to see the world according to their interpretation of it. Again, this is very much in keeping with the constructivist approach to representation, with montage being the essential aesthetic framing device.

Curtis and Del Naja can be seen as building on the aims of provocative artists and filmmakers such as Dziga Vertov, and by using similar techniques of signification, such as deconstructed montage and immersive live performance, are in essence maintaining a link between the avant-garde of the 1920s, the pop-artists of the 1960s, and the rave culture of the 1990s. Similar to Vertov's intention of creating a more informed reader of a film through filmic technique, Curtis and Del Naja invite the audience to experience a much "thicker" cinematic experience, in order to engage with sound and image on a deeper level, and as Aston points out, "the audience is bombarded with an intense sensory experience, intended to actively engage the viewer." ${ }^{30}$

For Aston, like Youngblood, the idea of experiencing an event live is absolutely key to the effectiveness of expanded cinema and expanded documentary. Aston calls this an emplaced interaction of the audience and argues that the live audio-visual documentary event engages our senses in ways that the traditional documentary form is not capable of, and "can be a way to engage our full complement of senses by bringing us together 
through physical co-presence." ${ }^{11}$ Here the reader can see that the scholars of documentary film still laud the potential of audio-visual culture as being progressive, in that it can create a sense of social and cultural cohesion. Nowadays the VJ has a plethora of creative techniques at his or her disposal, which are afforded through the usability and functionality of VJ hardware and software. Vertov could not have imagined the creative possibilities of such machines and could not have foreseen the inherent possibilities of having such a large database of images that could be chopped, looped, and sequenced in such sophisticated ways. It would certainly have been interesting to have seen what a film poet and theorist of Vertov's stature would have achieved with this machinery and availability of images. It seems that the spirit of filmmakers such as Dziga Vertov is very much alive today, with the concept of kinesis at the core of aesthetic approaches of audio-visual today.

\section{Conclusion}

With so much technology at the filmmaker's disposal, there is no reason why documentary should be confined to the edges of a two-dimensional screen. Virtual Reality offers a new form of exhibition, as do developments in interactive technology, which allows the audience to become active users, rather than passive consumers, of documentary film. Even gaming could incorporate documentary footage and become a new form of entertainment, information, and education. What is important for me, however, is that the filmmaker has the freedom to explore the very form of documentary itself, because it is at that level of audience perception that the political power of documentary resides, and as such, it is not about making political films, rather it is about making films politically.

\section{BIBLIOGRAPHY}

Aston, Judith. "Interactive Documentary and Live Performance: From Embodied to Emplaced Interaction." In Aston, J. Gaudenzi, S. and Rose, M. eds. I-Docs: The Evolving Practices of Interactive Documentary, New York: Wallflower Press, 2017, 222-236.

Beattie, Keith Beattie. Documentary Display: Re-Viewing Non-Fiction Film and Video, London: Wallflower Press, 2008.

Beattie, Keith. Documentary Screens: Nonfiction Film and Television, Basingstoke and New

York: Palgrave MacMillan, 2004.

Chion, Michel Chion. Audio-Vision: Sound on Screen, New York: Columbia University Press, 1994.

Cooper, David, Fox, Christopher, and Shapiro, Ian eds. Cinemusic: Constructing the Cine Score, Newcastle: Cambridge Scholars Press, 2008.

Hardy, Forsyth Hardy. John Grierson: A Documentary Biography, London: Faber and Faber, 1979. 
MacDougall, David. The Corporeal Image: Film, Ethnography, and the Senses, Princeton: Princeton University Press, 2006.

Nichols, Bill. Representing Reality, Bloomington: Indiana University Press, 1991.

Nichols, Bill. 'Documentary Film and the Modernist Avant-Garde' Critical Enquiry Vol. 27, No. 4 (summer, 2001).

Petrić, Vlada. Constructivism In Film, Cambridge: The Press Syndicate, 1978.

Renov, Michael. “Toward a Poetics of Documentary”, in Renov, Michael ed. (1993) Theorizing Documentary, London: Routledge, 1993, 12-36.

Wahlberg, Malin. Documentary Time: Film and Phenomenology, Minneapolis: University of Minnesota Press, 2008.

Youngblood, Gene. Expanded Cinema, New York: P. Dutton and Co, 1970.

\section{Filmography}

A Film About Nice (Keith Marley and Geoffrey Cox, 2010)

Regen (Joris Ivens, 1929)

Man With a Movie Camera (Dziga Vertov, 1929)

Enthusiasm (Dziga Vertov, 1931)

Berlin: Symphony of a Great City (Walter Ruttman, 1927)

À Propos de Nice (Jean Vigo, 1930)

Rien Que Les Heures (Alberto Cavalcanti, 1926)

\section{Expanded Documentary}

Exploding Plastic Inevitable (Andy Warhol and The Velvet Underground,1966, New York)

Mechanized Deconstruction (Keith Marley \& Geoffrey Cox, 2011, London)

SuperEverything (Light Surgeons, 2011, Malaysia)

Endless Cities (D-Fuse, 2012, Los Angeles)

Massive Attack V Adam Curtis (Manchester International Festival, 2013, Manchester)

A Thousand Thoughts (Sam Green, 2019, New York City)

\section{ENDNOTES}

1. For an in-depth discussion of Nichols' modes see Nichols (1991 and 2001).

2. Keith Beattie, Documentary Display: Re-Viewing Non-Fiction Film and Video. (London: Wallflower Press, 2008).

3. Gene Youngblood, Expanded Cinema (New York: P. Dutton and Co. 1970).

4. Michael Renov "Toward a Poetics of Documentary", in Renov ed., Theorizing Documentary (London: Routledge, 1993.), 35.

5. Dziga Vertov in Annette Michelson, The Writings of Dziga Vertov (Berkeley: University of California Press, 1984), 56.

6. John Grierson in Keith Beattie, Documentary Display: Re-Viewing Non-Fiction Film and Video, 10.

7. Bill Nichols, Representing Reality (Bloomington: Indiana University Press, 1991), 3. 
8. Keith Beattie, Documentary Screens: Nonfiction Film and Television (Basingstoke and New York: Palgrave MacMillan, 2004), 17.

9. Forsyth Hardy, John Grierson: A Documentary Biography (London: Faber and Faber, 1979), 40-41.

10. Keith Beattie, Documentary Display: Re-Viewing Non-Fiction Film and Video, 5.

11. Ibid, 29.

12. To view A Film About Nice go to: https://vimeo.com/208977546

13. Keith Beattie, Documentary Display: Re-Viewing Non-Fiction Film and Video, 6.

14. David MacDougal, The Corporeal Image: Film, Ethnography, and the Senses, 4.

15. Keith Beattie, Documentary Display: Re-Viewing Non-Fiction Film and Video, 6.

16. Michael Renov, “Toward a Poetics of Documentary”, 35.

17. Michel Chion, Audio-Vision: Sound on Screen (New York: Columbia University Press. 1994), 10-11

18. Geoffrey Cox and Keith Marley, "Looking and Listening" in David Cooper, Christopher Fox, and Ian Shapiro eds., Cinemusic: Constructing the Cine Score (Newcastle: Cambridge Scholars Press. 2008), 58.

19. David MacDougall, The Corporeal Image: Film, Ethnography, and the Senses, 27.

20. Gene Youngblood, Expanded Cinema, 103.

21. I use this term to refer to a person who uses machines/computer software that are associated with club culture, in the context of live audio-visual performance.

22. Caroline Tisdall and Aneglo Bozzolla, Futurism (London: Thames and Hudson, 1977), 8.

23. Malin Wahlberg, Documentary Time: Film and Phenomenology, (Minneapolis: University of Minnesota Press, 2008), xiv-xv.

24. Malin Wahlberg, Documentary Time: Film and Phenomenology, 27

25. Gene Youngblood, Expanded Cinema, 97.

26. Vlada Petrić, Constructivism In Film (Cambridge: The Press Syndicate, 1978), 27.

27. Vlada Petrić, Constructivism In Film, 27.

28. Gene Youngblood. Expanded Cinema, 97.

29. Vlada Petrić, Constructivism In Film, 27.

30. Judith Aston. "Interactive Documentary and Live Performance: From Embodied to Emplaced Interaction." In Judith Aston, Sandra Gaudenzi, and Mandy Rose eds., I-Docs: The Evolving Practices of Interactive Documentary. (New York: Wallflower Press, 2017), 228.

31. Judith Aston, 'Interactive Documentary and Live Performance: From Embodied to Emplaced Interaction.' 234.

\section{ABSTRACTS}

In this article I make the claim that aesthetic strategies associated with the Modernist avantgarde can provide a tangible source of entertainment for audiences. I contextualize this through Keith Beattie's concept of "documentary display". I use the film work of others, as well as my own documentary practice, to illustrate this. In doing this, I offer an explanation of my intentions as a filmmaker in order to show how I aim to engage audiences in particular ways through the adoption of certain aesthetic approaches to documentary filmmaking. I also discuss my own concept of 'expanded documentary' in order to explain how alternative forms of 
exhibition, as well as specific aesthetic approaches to filmmaking, can be seen as having the principle of entertainment at documentary's core. I build on Gene Youngblood's work on "expanded cinema" and again use the work of others, as well as my own film practice, to illustrate this.

INDEX

Keywords: Constructivism; Futurism; Poetic Mode; Cinema of Attractions; Expanded Cinema; Live Performance of Documentary; Dziga Vertov; Documentary Display; Sensory Perception

\section{AUTHOR}

\section{KEITH MARLEY}

Dr. Marley is a senior lecturer in Film Studies at Liverpool John Moores University, LJMU, and documentary filmmaker. His main areas of research focus on documentary aesthetics and he is particularly interested in the work and writings of Dziga Vertov. 